\title{
Is re-biopsy necessary for benign breast cytology? - a case report of an occult rare malignancy: marginal zone lymphoma of the breast
}

\section{Benign meme sitolojilerinde biyopsi tekrarı gerekli midir? - Nadir görülen bir gizli malignitenin olgu sunumu: marjinal zon lenfoma}

\author{
Funda Ulu Öztürk, Şehnaz Tezcan, Nihal Uslu \\ Department of Radiology, Başkent University, Ankara, Turkey
}

Dergiye Ulaşma Tarihi: 08.09.2017 Dergiye Kabul Tarihi: 11.09.2017 Doi: 10.5505/aot.2017.84856

\begin{abstract}
ÖZET
Primer meme lenfoması spesifik görüntüleme özellikleri olmayan nadir bir antitedir. Tek taraflı veya bilateral meme tutulumu izlenebildiği gibi bölgesel lenf nodu tutulumu ile de prezente olabilir. Radyolojik algoritma meme kitlelerinin tanısı için olduğu kadar takipler için de önem taşımaktadır. Olgumuz 77 yaşında kadın hasta olup sol memesinde ele gelen şişlik ile başvurmuştur ve biyopsisi benign sitoloji olarak sonuçlanmıştır. Kontrol takibinde kitlenin büyümesi üzerine tekrar biyopsi yapılmış ve sonuç marjinal zon lenfoma olarak rapor edilmiştir. Evreleme çalışmasının evre IE lokal hastalık olarak belirlenmesi üzerine hastaya tedavi için sadece radyoterapi verilmiştir. Hasta 13 aydır takip edilmekte olup komplet remisyondadır. Tek başına ince iğne aspirasyon biyopsisi, lenfoid hücreleri reaktif lenfositlerden ayırt etmede güçlüğe sebep olduğu için primer meme lenfoması için yetersiz bir yöntemdir. Bu sebeple bu vakada olduğu gibi şüpheli meme kitlelerinde kor biyopsi, eksizyonel biyopsi ya da yakın takiplerle hastaların değerlendirilmesi gerekmektedir.

Anahtar Kelimeler: primer meme lenfoması, marjinal zon lenfoma, kor biyopsi
\end{abstract}

\section{ABSTRACT}

Primary breast lymphoma is a rare entity which does not have specific imaging features. It can involve one or both breasts as well as regional lymph nodes. Radiological algorithm is essential for breast lumps as well as followups. We report here a case of a 77 year-old woman with a mass in her left breast, which was lead to biopsy priorly and resulted in benign cytological findings. Re-biopsy due to the enlargement of the mass in follow-up revealed marginal zone lymphoma. After a staging work-up she was found to have a local disease in stage IE. She was treated only with radiotherapy and is now in complete remission after 13 months. Fine needle aspiration alone is inadequate for primary breast lymphoma, regarding the difficulty of its defect of distinguishing lymphoid cells from reactive lymphocytes. Either adequate tissue biopsy, by a core needle or excisional biopsy, or close followups are needed for suspicious breast masses, presented as in this case.

Keywords: primary breast lymphoma, marginal zone lymphoma, core biopsy.

\section{Introduction}

Primary breast lymphoma (PBL) is a rare malignancy of the breast which includes about $0.5 \%$ of all primary malignant neoplasms of the breast. It is also an unusual location for extranodal lymphoma which represents less than $1 \%$ of all non-Hodgkin's lymphomas. Diagnostic approach to PBL is similar to that of breast carcinoma. The difference is that PBL is more indolent than carcinoma and the treatment strategies are not standard in guidelines regarding to its scarce incidence $(1,2)$. We report here a case of marginal zone lymphoma in breast, which could not be recognized by fine needle aspiration, but later suspected for

Adress for correspondence: Department of Radiology, Başkent University, Ankara, Turkey e-mail: nepandes@hotmail.com

Available at www.actaoncologicaturcica.com

Copyright $\odot$ Ankara Onkoloji Hastanesi enlargement during the follow-ups and diagnosed with a re-biopsy.

\section{Case}

A 77 year-old woman with a lump in the left breast admitted to general surgery department of our hospital. History of the patient revealed that she has been followed-up in another clinic for this breast mass. In her prior breast ultrasounds, no notice of grow of the mass was observed, but regarding to the size and lobulated contours biopsy procedure was planned. The mass biopsy resulted in benign histopathological findings and the patient was 
recalled in routine follow-up time. After a long gap of 4 years, the patient visited our hospital and detailed physical examination was done. She did not have any symptom or finding other than the lump in her breast. She also had negative family history of breast cancer. The general surgent requested a mammography control. The mammography revealed an asymetric tissue field in the upper internal quadrant of her left breast with unclear margins superposed with glandular tissue and ultrasound was suggested (Figure 1). The ultrasound findings were much similar to that of performed in 2012 priorly, except that the mass in her left breast grew in size and was hypervascular (Figure 2). No axillary lymphadenopathy was detected. Re-biopsy was suggested. Ultrasound guided tru-cut biopsy was performed in the radiology department with $16 \mathrm{G}$ needle. The specimen obtained was evaluated as atypical lymphoid infiltration which was interpretted as a suspicious low grade lymphoproliferative malignancy, and excisional biopsy was suggested. Immediately afterwards, the mass was removed followed by stereotactic breast biopsy. Histopathological and immunohistochemical findings in the mass confirmed the diagnosis of a extranodal marginal zone lymphoma with CD20+, CD3+, bcl2+, CD23+, CD10-, CD5-, CD43-, bcl6-, Cyclin D1-. Paraffin-section studies were positive for Ki-67 highly in the residual germinal centers. There were no abnormalities in computerized tomography (CT) of the thorax and abdomen. No peripheral lymphadenopaty was detected in the ultrasound of cervical lymphatic chains and inguinal regions. PET/CT scan showed no significant uptake. Bone morrow analysis was performed for the last step of staging and it did not reveal lymphoma infiltration. Therefore, the patient was diagnosed with stage IE according to the Ann Arbor claasification. Regarding the limited stage of the disease, only radiation theraphy was introduced and no complication was noted during the treatment. Contol breast ultrasound examination after 6 months defined a hypoechoic region in the surgery zone and breast magnetic resonance imaging (MRI) confirmed benign postoperative changes in this area. No other abnormalities were found and thus, this was considered as complete remission. During a 7 month follow-up period no relapse was observed.

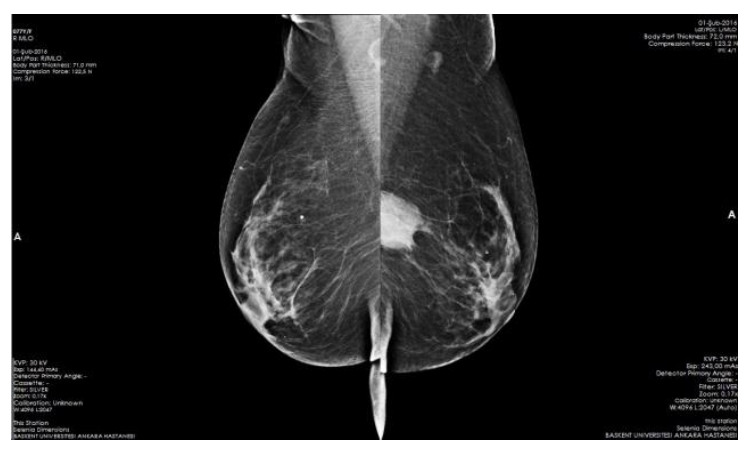

Figure 1. Mediolateral oblique mammograms of both breasts. There was asymetric tissue field in the upper part of her left breast with unclear margins superposed with glandular tissue

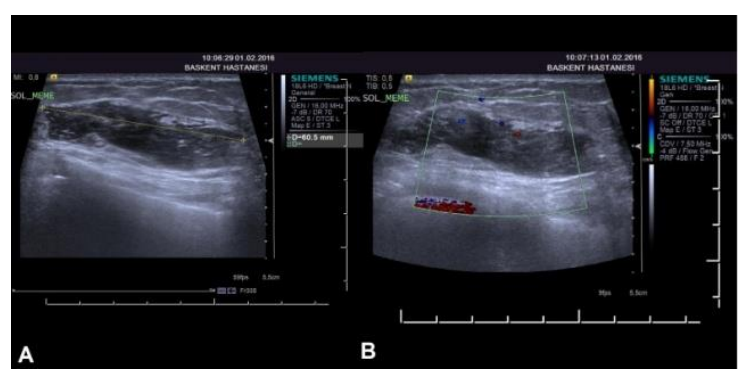

Figure 2. Ultrasound and Doppler ultrasound images of the mass. a, Ultrasound images. There was an oval shaped, well-defined, heterogenously hypoechoic large mass in the left breast $\mathbf{b}$, Color Doppler ultrasound images. There were peripherally vascularised areas within the mass

\section{Discussion}

Primary breast lymphoma (PBL) is a rare entity of the breast and a rare location for extranodal lymphoma (2). It was first defined by Wiseman and Liao in 1972, described as the lymphoma infiltration of breast tissue in patients who did not have any nodal or extranodal lymphoma and systemic disease until the time of diagnosis. Regional lymph nodes may be present or not (3). The presentation of PBL is mostly a painless growing breast mass in elderly patients. The median age ranges from 60 to 65 years. Bilateral involvement is not very rare, which is $11 \%$ of all breast lymphomas. Male cases are very few (less than 5\%), where women are affected predominantly $(2,4,5)$.

Diffuse large B-cell lymphoma represents the majority of PBLs. Marginal zone lymphoma (MZL), a very rare variant, is considered as low 
grade histological subtype of PBL together with follicular lymphoma, which comprises $9 \%$ and $14 \%$ of all primary breast lymphomas, respectively (6). Low grade tumors, such as MZL, do not present with symptoms of advanced disease including "B" symptoms (fever, night sweats, $10 \%$ weight losswithin half a year), central nervous system symptoms, and bulky lymphadenopathy. It is important to distinguish PBL from breast carcinoma for the clinician, regarding the difference of treatment and prognosis between the two entities. PBLs are usualy greater in size compared to epithelial breast cancers and tend to enlarge rapidly $(2,5)$.

The radiological diagnostic algorithm includes mammography, ultrasonography, MRI and positron emission tomography. Mammographic features are reported as solitary, uncalcified soft-tissue mass by Liberman et al. The borders might be well or partially circumscribed (7). Our case revealed a solitary asymetric tissue field with unclear margins superposed with glandular tissue. Ultrasound features are not specific for any lymphomatoid disease. Contours range from sharp to poor, the echo pattern vary from hypoto hyperechoic, but mostly hypoechoic, whereas involvement can be focal or diffuse $(4,8)$. In our case, there was a solitary, oval shaped, welldefined, large $(6 \mathrm{~cm})$, heterogenously hypoechoic mass with peripherally vascularised areas. MRI features include ill-defined, nonspiculated, hypointense masses in T1W images. In dynamic study there is rapid and strong enhancement with peripheral rim. These are similar findings with breast carcinoma, therefore not specific for PBL (8). In our case, the mass was excised right after core biopsy, therefore MRI could not be performed before surgery.

Fine needle aspiration, core biopsy and excisional biopsy are used to evaluate cytological and histopathologic features in diagnosing PBL. Fine needle aspiration cytology can show atypical lymphoid cells suggestive of malignancy but it also can be insufficient alone distinguishing between lymphoid cells and reactive lymphocytes. Therefore, core biopsy or surgical biopsy with sufficient tissue material is essential in order to make a proper histopathologic evaluation and immunophenotyping $(2,5)$. In our case, the patient had a fine needle biopsy priorly, which resulted in benign pathological findings. Therefore she was put in a follow-up program. We think that if she had a tru-cut biopsy or an excisional biopsy, the diagnosis of this low grade tumor could have been made even earlier.

For staging PBL, physical examination together with a careful history and a series of studies are recommended such as thoracoabdominal CT or PET-CT, bone marrow aspiration, biopsy and laboratory findings (CBC, comprehensive metabolic panel). Luganos modification of the Ann Arbor staging system is used for defining the stage of extranodal lymphoma. According to this system, without "B" symptoms, disease limited to breast only is stage IE and if there is an ipsilateral lymph node involvement together with lesion limited to breast, then it is stage IIE (2). Considering Ann Arbor criteria, we defined our case as stage IE.

The management strategies for PBL include surgery, chemotherapy and radiotherapy alone or in combination. There is no up to date standard guideline treatment. The biological behavior of the lymphoma guides to choose the appropriate protocol. Systemic therapy (chemotherapy) or local treatment (surgery and/or radiotherapy) are of the options. For best survival rates, chemotheraphy alone or combined with local treatment is offered for aggressive subtypes, such as diffuse large B-cell lymphoma. On the other hand, for low grade lymphomas, local treatment alone would be enough (2). Mastectomy is not recommended, because there is no better survival rates nor reduced risk of recurrence reported. Besides, as a major surgery it has a high risk of morbidity, while axillary dissection doesn't provide any therapeutic advantage. Most of the surgical procedures are carried out either for obtaining tissue diagnosis by a minor surgery or for misdiagnosed lesions which are thought to be poorly differentiated breast carcinoma $(2,5)$. The most common chemotherapy agents used for PBL are those in CHOP regimen (4). The treatment for the ultimate control of the disease in localized stage MZL is recommended as radiotherapy alone in stage IE and combined chemotherapy in stage IIE. MZL is reported to have a better prognosis compared to diffuse large B-cell lymphoma and follicular 
lymphoma (2). In our case, we performed an excisional biopsy and since being only in stage IE, radiation therapy was used alone after the surgery. The patient is free of relapse after 13 months following the surgery and radiotherapy, which is considered to be complete remission.

\section{Conclusion}

In conclusion, PBL is a rare form of extranodal lymphoid neoplasm, and its indolent subtype

\section{References:}

1. Franco Pérez F, Lavernia J, Aguiar-Bujanda D, Miramón J, Gumá J, Álvarez R, et al. Primary Breast Lymphoma: Analysis of 55 Case $\mathrm{s}$ of the Spanish Lymphoma Oncology Group. Clin Lymphoma Myeloma $\quad$ Leuk 2017 Mar;17(3):186-191. doi: 10.1016/j.clml.2016.09.004.

2. Koganti SB, Lozada A, Curras E, Shah A. Marginal zone lymphoma of the breastA diminished role for surgery. Int $\mathrm{J}$ Surg Case Rep 2016;25:4-6. doi: 10.1016/j.ijscr.2016.05.041.

3. Wiseman C, Liao K. Primary lymphoma of the breast. Cancer 1972; 29:1705-12.

4. Joks M, Myśliwiec $\mathrm{K}$, Lewandowski $\mathrm{K}$. Primary breast lymphoma - a review of the literature and report of three cases. Arch Med Sci $2011 \quad$ Feb;7(1):27-33. doi: 10.5114/aoms.2011.20600.
MZL is even rarer. Although there is a lack of a standard treatment in PBLs, chemotherapy is still the basis of systemic disease, where low grade tumors and resected disease can be treated with radiotherapy. Radiological investigations are essential but not specific for the diagnosis of PBL, which should finally be confirmed by pathology. This case emphasizes the necessity of close follow-up and re-biopsy in patients even diagnosed as benign by fine needle aspiration, especially considering slowly enlarging breast masses.

\section{Conflict of interest: None}

5. Jabbour G, El-Mabrok G, Al-Thani H, ElMenyar A, Al Hijji I, Napaki S. Primary Breast Lymphoma in a Woman: A Case Report and Review of the Literature. Am J Case Rep 2016 Feb 19;17:97-103.

6. Martinelli G, Ryan G, Seymour JF, Nassi L, Steffanoni S, Alietti A, et al. Primary follicular and marginalzone lymphoma of

the breast: clinical features, prognosticfactors an d outcome: a study by the International Extranodal Lymphoma Study G roup. Ann Oncol 2009 Dec;20(12):1993-9. doi: 10.1093/annonc/mdp238.

7. Liberman L, Giess CS, Dershaw DD, Louie DC, Deutch BM. Non-Hodgkin lymphoma of the breast: imaging characteristics and correlation with histopathologic findings. Radiology 1994;192:157-60.

8. Demirkazik FB. MR imaging features of breast lymphoma. Eur J Radiol 2002 Apr;42(1):62-4. 